Рекомендована д. фрармац. наук, проф. В. В. Трохимчуком

УДК 65.1:616.322 - 002.1 - 085:338.5

DOI 10.11603/2312-0967.2016.4.7121

\title{
КЛІНІКО-ЕКОНОМІЧНИЙ АНАЛІЗ ВИТРАТ НА ФАРМАКОТЕРАПІЮ ГОСТРОГО ТОНЗИЛІТУ В УМОВАХ СТАЦІОНАРУ
}

\author{
() А. М. Машейко, О. В. Макаренко, В. В. Маврутенков \\ ДЗ «Дніпропетровська медична академія мОЗ України», Дніпро
}

Резюме: у статті наведено результати інтегрованого частотного/VEN/ABC-аналізу доцільності фрінансових витрат
на проведення фармакотерапії гострого тонзиліту. Встановлено суттєву перевагу частоти лікарських призначень
другорядних засобів (N) над життєво важливими (V) у кількісному вираженні та незначну перевагу життєво
важливих засобів над другорядними у вартісному вираженні. 3 отриманих результатів можна зробити висновок, що
основні фрінансові кошти не витрачались на необхідні та важливі лікарські засоби для лікування гострого тонзиліту.

Ключові слова: гострий тонзиліт, частотний аналіз, ABC-аналіз, VEN-аналіз, лікування в умовах стаціонару.

Вступ. Гострий тонзиліт або ангіна (J03 за MKX10) $є$ одним з найбільш поширених захворювань дихальної системи у дітей та підлітків [1]. Відповідно до протоколу лікування, затвердженого МОЗ України, медична допомога таким хворим надається або амбулаторно (при катаральній фрормі гострого тонзиліту), або в умовах стаціонару (при фолікулярній та лакунарній формах тонзиліту) [2].

Згідно з останніми даними Державного комітету статистики, 41,1 \% коштів у структурі загальних витрат на охорону здоров'я складають приватні кошти громадян [3]. При цьому за рахунок цих коштів покривається 99,6 \% витрат на придбання фрармацевтичних товарів для амбулаторного лікування та 86,7 \% - для стаціонарного [4]. Поряд з цим слід наголосити на низьку купівельну спроможність хворих, оскільки 36,1% з них не мають змоги придбати призначені лікарем препарати [5].

Зважаючи на високі показники захворюваності населення, постійно зростаючі витрати на лікування та низьку купівельну спроможність хворих, мета нашої роботи полягала в дослідженні доцільності фрінансових витрат на проведення фрармакотерапії гострого тонзиліту на основі результатів ретроспективного клініко-економічного аналізу медичних карток стаціонарних хворих.

Методи дослідження. Матеріалом нашого дослідження були листи лікарських призначень (форма №003-4/o) 290 хворих на гострий тонзиліт віком від 2 до 18 років, що перебували на стаціонарному лікуванні в закладах охорони здоров'я Дніпропетровського регіону за період 2013 - 2015 роки. Загалом було проаналізовано 1709 препаратів. Відповідність лікарських призначень досліджувалась шляхом їх порівняння 3 чинним протоколом надання медичної допомоги хворим на гострий тонзиліт [2] та Державним фрормуляром лікарських засобів України [6]. Для аналізу частоти призначень лікарських засобів, їх ранжування за витратністю та ступенем важливості для лікування досліджуваної нозології застосовували інтегрований частотний/VEN/ABC-аналіз [7].

Результати й обговорення. На першому етапі дослідження був проведений формальний VEN-аналіз. Критерієм віднесення лікарських засобів до категорії «У» (життєво необхідні) була їх наявність в протоколі надання медичної допомоги хворим на гострий тонзиліт [2] та Державному фрормулярі лікарських засобів України [6] з урахуванням можливості їх призначення дітям та підліткам, що затверджено в інструкції для медичного застосування препаратів. До категорії «N» (другорядні) потрапили лікарські засоби, які не були віднесені до жодного з вищезазначених нормативних документів.

Для оцінки відповідності лікарських призначень віковим показанням до застосування досліджуваних препаратів хворих розділили на три вікові групи: 1 група ( $\mathrm{n}=38)$ - діти від 2 до 4 років; 2 група $(\mathrm{n}=153)$ - діти від 5 до 11 років; 3 група $(\mathrm{n}=99)$ - підлітки від 12 до 18 років. Так, першій групі пацієнтів (2-4 роки) було призначено $45 \mathrm{MHH}$, що відповідало 62 торговим найменуванням, з яких 15 МНН не дозволено застосувати дітям до 4-х років. Хворим другої групи (5-11 років) було призначено $92 \mathrm{MHH}(163 \mathrm{TH}), 3$ яких $13 \mathrm{MHH}$ не дозволено застосовувати дітям зазначеної вікової категорії. Хворим третьої групи (старше 12 років) $70 \mathrm{MHH}$ із $75 \mathrm{MHH}$ було призначено правильно відповідно до вікових показань, затверджених в інструкції. Загалом 15 \% (257 із 1709) лікарських призначень не відповідали віковим показанням, що зазначені в інструкції для медичного застосування, серед яких найбільш поширеною помилкою було призначення препаратів диклофренаку, дифренгідраміну і декаметоксину особам молодше 15 років та використання спреїв для зрошування горла у дітей віком до 6 років.

За результатами фрормального VEN-аналізу було встановлено, що близько 25 \% лікарських призначень (424 із 1709) належали до життєво важливих засобів

ISSN 2312-0967. Фармацевтичний часопис. 2016. № 4 
категорії «V» і 75 \% призначень являли собою другорядні препарати категорії «N». Таким чином, отримані дані свідчать про нераціональність використання фрінансових ресурсів, що перед усім пов'язано з недостатнім дотриманням лікарями національних стандартів лікування [2, 6]. У листках лікарських призначень, окрім стандартної фрармакотерапії, додатково призначались засоби локальної антисептичної дії, препарати для нормалізації мікрофрлори кишечника, глюкокортикостероїди, дієтичні добавки, також спостерігалось недостатнє дотримання вікових показань до застосування лікарських засобів та використання антибіотиків при гострому тонзиліті вірусного походження.

Для оцінки домінуючих напрямків фрармакотерапії гострого тонзиліту наступним етапом нашого дослідження було проведення частотного аналізу лікарських призначень шляхом визначення частки хворих, яким призначався певний лікарський засіб (табл. 1). За результатами аналізу було встановлено, що всім пацієнтам (n=290) призначались антибактеріальні препарати

Таблиця 1. Частотний аналіз лікарських призначень для лікування гострого тонзиліту

\begin{tabular}{|c|c|c|}
\hline Фармакотерапевтична група & $\begin{array}{c}\text { МНH } \\
\text { код АТС }\end{array}$ & $\begin{array}{c}\text { Частота } \\
\text { призначень } \\
\text { кількість хворих } \\
\text { \% хворих }\end{array}$ \\
\hline 1 & 2 & 3 \\
\hline $\begin{array}{c}\text { Протимікробні для системного застосування; } \\
\text { цефралоспорини } \\
\text { III покоління }\end{array}$ & $\begin{array}{l}\text { Цестріаксон } \\
\text { J01D D04 }\end{array}$ & $228 / 78,62$ \\
\hline $\begin{array}{c}\text { Препарати, що застосовуються при } \\
\text { захворюваннях горла }\end{array}$ & $\begin{array}{l}\text { Різні антисептики } \\
\text { R02A A20 }\end{array}$ & $193 / 66,55$ \\
\hline Анальгетики та антипіретики & Метамізол натрій N02B B02 & $137 / 47,24$ \\
\hline Кровозамінники та перфузійні розчини & Розчини для перфузії В05 & $110 / 37,93$ \\
\hline Препарати гормонів для системного застосування & Глюкокортикостероїди Н02А В & $96 / 33,10$ \\
\hline Засоби, що впливають на травну систему & $\begin{array}{c}\text { Антидіарейні мікробні препарати } \\
\text { A07F A }\end{array}$ & $88 / 30,34$ \\
\hline $\begin{array}{c}\text { Антигістамінні засоби для системного } \\
\text { застосування }\end{array}$ & $\begin{array}{c}\text { Дифенгідрамін } \\
\text { R06AA02 }\end{array}$ & $84 / 28,97$ \\
\hline Нестероїдні протизапальні засоби & $\begin{array}{l}\text { Диклосренак } \\
\text { М01А В05 }\end{array}$ & $82 / 28,28$ \\
\hline $\begin{array}{c}\text { Антигістамінні засоби для системного } \\
\text { застосування }\end{array}$ & $\begin{array}{l}\text { Хлоропірамін } \\
\text { R06А C03 }\end{array}$ & $63 / 21,72$ \\
\hline $\begin{array}{l}\text { Протимікробні для системного застосування; } \\
\text { макроліди }\end{array}$ & $\begin{array}{l}\text { Азитроміцин } \\
\text { J01F A10 }\end{array}$ & $58 / 20,00$ \\
\hline $\begin{array}{c}\text { Препарати, що застосовуються при } \\
\text { захворюваннях горла } \\
\end{array}$ & $\begin{array}{c}\text { Декваліній } \\
\text { R02A A02 } \\
\end{array}$ & $44 / 15,17$ \\
\hline Засоби, що впливають на респіраторну систему & $\begin{array}{c}\text { Протинабрякові та інші препарати } \\
\text { для місцевого застосування у разі } \\
\text { захворювань порожнини носа R01A }\end{array}$ & $39 / 13,45$ \\
\hline Протизапальні засоби для місцевого застосування & $\begin{array}{l}\text { Бензидамін } \\
\text { A01A D02 } \\
\end{array}$ & $38 / 13,10$ \\
\hline Нестероїдні протизапальні засоби & $\begin{array}{l}\text { Ібупрофрен } \\
\text { М01А E01 }\end{array}$ & $35 / 12,07$ \\
\hline Антисептичні та дезінфекційні засоби & $\begin{array}{l}\text { Нітрофрурал } \\
\text { D08A F01 }\end{array}$ & $32 / 11,03$ \\
\hline $\begin{array}{c}\text { Протимікробні засоби для системного } \\
\text { застосування; цефалоспорини } \\
\text { II покоління }\end{array}$ & $\begin{array}{l}\text { Цесруроксим } \\
\text { J01D C02 }\end{array}$ & $29 / 10,00$ \\
\hline Засоби, що впливають на метаболізм & $\begin{array}{c}\text { Вітаміни } \\
\text { A11 } \\
\end{array}$ & $29 / 10,00$ \\
\hline Дієтичні добавки & Дієтичні добавки & $24 / 8,28$ \\
\hline Противірусні засоби прямої дії & $\begin{array}{l}\text { Інозин пранобекс } \\
\text { J05А Х05 }\end{array}$ & $21 / 7,24$ \\
\hline $\begin{array}{c}\text { Препарати, що застосовуються при } \\
\text { захворюваннях горла }\end{array}$ & $\begin{array}{c}\text { Фенол } \\
\text { R02AA19 }\end{array}$ & $19 / 6,55$ \\
\hline
\end{tabular}

ISSN 2312-0967. Pharmaceutical review. 2016. № 4 
Продовження табл. 1

\begin{tabular}{|c|c|c|}
\hline 1 & 2 & 3 \\
\hline Анальгетики та антипіретики & $\begin{array}{l}\text { Парацетамол } \\
\text { N02B E01 }\end{array}$ & $18 / 6,21$ \\
\hline $\begin{array}{c}\text { Препарати, що застосовуються при } \\
\text { захворюваннях горла }\end{array}$ & $\begin{array}{l}\text { Фузафрунгін } \\
\text { R02A B03 }\end{array}$ & $14 / 4,83$ \\
\hline $\begin{array}{c}\text { Протимікробні засоби для системного } \\
\text { застосування; фрторхінолони }\end{array}$ & $\begin{array}{l}\text { Левофрлоксацин } \\
\text { J01М A12 }\end{array}$ & $9 / 3,10$ \\
\hline $\begin{array}{c}\text { Протимікробні засоби для системного } \\
\text { застосування; цефалоспорини } \\
\text { III покоління }\end{array}$ & $\begin{array}{l}\text { Цефріксим } \\
\text { J01D D08 }\end{array}$ & $8 / 2,76$ \\
\hline $\begin{array}{c}\text { Протимікробні засоби для системного } \\
\text { застосування; інгібіторозахищені пеніциліни }\end{array}$ & $\begin{array}{l}\text { Ампіцилін та сульбактам } \\
\text { J01C R01 }\end{array}$ & $8 / 2,76$ \\
\hline $\begin{array}{c}\text { Протимікробні засоби для системного } \\
\text { застосування; інгібіторозахищені пеніциліни }\end{array}$ & $\begin{array}{l}\text { Амоксицилін та } \\
\text { клавуланат } \\
\text { J01C R02 }\end{array}$ & $8 / 2,76$ \\
\hline $\begin{array}{c}\text { Протимікробні для системного застосування; } \\
\text { тетрацикліни }\end{array}$ & $\begin{array}{l}\text { Доксициклін } \\
\text { J01АА02 }\end{array}$ & $6 / 2,07$ \\
\hline $\begin{array}{c}\text { Протимікробні засоби для системного } \\
\text { застосування; природні пеніциліни }\end{array}$ & $\begin{array}{c}\text { Бензилпеніцилін, комбінації J01C } \\
\text { Е30 }\end{array}$ & $5 / 1,72$ \\
\hline $\begin{array}{c}\text { Протимікробні засоби для системного } \\
\text { застосування; цефалоспорини } \\
\text { III покоління }\end{array}$ & $\begin{array}{l}\text { Цефрподоксим } \\
\text { J01D D13 }\end{array}$ & $4 / 1,38$ \\
\hline $\begin{array}{c}\text { Протимікробні засоби для системного } \\
\text { застосування; інгібіторозахищені цефалоспорини }\end{array}$ & $\begin{array}{l}\text { Цефртріаксон та сульбактам } \\
\text { J01D D54 }\end{array}$ & $4 / 1,38$ \\
\hline $\begin{array}{c}\text { Протимікробні засоби для системного } \\
\text { застосування; пеніциліни широкого спектра дії }\end{array}$ & $\begin{array}{c}\text { Амоксицилін } \\
\text { J01С А04 } \\
\end{array}$ & $3 / 1,03$ \\
\hline $\begin{array}{c}\text { Протимікробні засоби для системного } \\
\text { застосування; цефалоспорини } \\
\text { III покоління }\end{array}$ & $\begin{array}{l}\text { Цефотаксим } \\
\text { J01D D01 }\end{array}$ & $3 / 1,03$ \\
\hline $\begin{array}{c}\text { Протимікробні засоби для системного } \\
\text { застосування; цефалоспорини } \\
\text { III покоління }\end{array}$ & $\begin{array}{l}\text { Цестазидим } \\
\text { J01D D02 }\end{array}$ & $2 / 0,69$ \\
\hline $\begin{array}{c}\text { Протимікробні засоби для системного } \\
\text { застосування; цефалоспорини } \\
\text { III покоління }\end{array}$ & $\begin{array}{l}\text { Цесроперазон } \\
\text { J01D D12 }\end{array}$ & $1 / 0,34$ \\
\hline $\begin{array}{c}\text { Протимікробні засоби для системного } \\
\text { застосування; цесралоспорини } \\
\text { III покоління }\end{array}$ & $\begin{array}{l}\text { Цестибутен } \\
\text { J01D D14 }\end{array}$ & $1 / 0,34$ \\
\hline $\begin{array}{c}\text { Протимікробні засоби для системного } \\
\text { застосування; природні пеніциліни }\end{array}$ & $\begin{array}{l}\text { Бензилпеніцилін } \\
\text { J01C Е01 }\end{array}$ & $1 / 0,34$ \\
\hline
\end{tabular}

для системного застосування, серед яких у 78,62 \% хворих перевагу надавали цефтріаксону. При цьому за результатами мікробіологічної діагностики, лише у 20 \% досліджуваних хворих було ідентифіковано збудника захворювання бактеріального походження. Отже, у 80 \% випадків доцільність призначення антибіотику була сумнівною. Пеніциліни, які за даними доказової медицини визнані препаратами вибору для лікування стрептококового тонзиліту [8], призначали менш ніж у 5 \% хворих. Разом з системними антибактеріальними засобами кожен пацієнт отримував протимікробні засоби місцевої дії (R02AA, R02AB, D08A та A01A). У великій кількості випадків одному хворому призначалось по 2-3 локальні антисептики одночасно. Варто зауважити, що через відсутність доказових даних щодо клінічної ефек- тивності зазначеної групи засобів протоколом надання медичної допомоги хворим на гострий тонзиліт [2] ці препарати не рекомендовані.

Більш ніж у половини хворих застосовувалась симптоматична терапія за допомогою антигістамінних препаратів, ненаркотичних анальгетиків та нестероїдних протизапальних засобів, серед яких найбільш часто призначалась комбінація метамізол натрій 3 дифегідраміном та диклофенак. Відповідно до вікових показань дітям та підліткам вищезгадані засоби застосовувати не можна, що пов'язано з ризиком виникнення серйозних побічних реакцій. Натомість, парацетамол та ібупрофен, що рекомендовані до застосування в педіатричній практиці, призначались лише у 6 \% та 12 \% хворих відповідно.

ISSN 2312-0967. Фармацевтичний часопис. 2016. № 4 
Другорядні засоби - глюкокортикостероїди, перфрузійні розчини та препарати для нормалізації мікрофрлори кишечника призначались третині пацієнтів 3 гострим тонзилітом. При цьому застосування перелічених засобів протоколом надання медичної допомоги [2] та Державним фрормуляром [6] не передбачено.

Таким чином, порівнюючи отримані дані з чинними протоколами лікування, можна зробити висновок про недостатню відповідність призначуваного лікування національним клінічним стандартам та наявність поліпрагмазії у приписах лікарів.

Наступний етап дослідження полягав в ранжуванні призначуваних лікарських засобів на три групи залежно від суми фрінансових витрат на них: «А» (найбільш витратні) - засоби, на які витрачається основний обсяг коштів, «В» (середньо витратні) та «С» (найменш витратні). Оскільки значна кількість засобів, що призначалась при лікуванні гострого тонзиліту, не була внесена до Реєстру оптово-відпускних цін МОз України, отже не могла закуповуватись за гроші державного бюджету [9], а тому купувалась хворими за власні кошти, вартість курсу лікування ми розраховували виходячи зі середньозваженої роздрібної вартості упаковки [10]. Ціни на лікарські засоби визначались одномоментно станом на січень 2016 року. За результатами ABC-аналізу 290 хворим було призначено 1709 найменувань лікарських засобів на загальну суму 170767 грн (табл. 2).

Встановлено, що на 450 (26,33\%) лікарських засобів, що склали групу А, витрачено 95806 грн (56,10 \% від усіх витрат), на 580 (33,94 \%) лікарських засобів групи В - 53006 грн (31,04 \% від усіх витрат), на 679 (39,73 \%) лікарських засобів групи С - 21955 грн (12,86 \% від усіх витрат).

Отже, не досить сумлінне дотримання лікарями протоколу лікування [2] призвело до призначення значної кількості розрізнених додаткових препаратів, внаслідок чого структура витрат на фрармакотерапію гострого тонзиліту не дозволяє контролювати $80 \%$ фінансових коштів за допомогою контролю $20 \%$ асортименту призначуваних ліків.

Останнім етапом нашого дослідження було зіставлення результатів частотного, VEN- та ABC-аналізу (табл. 3).

Інтегрований частотний/VEN/ABC-аналіз показав, що до найбільш витратної групи А увійшло 15,04\% (257 із 1709) лікарських засобів категорії V та 11,29 \% (193 із 1709) лікарських засобів категорії $\mathrm{N}$, що за часткою витрат дорівнювало 48,9 \% (83503 із 170767 грн) та 7,2 \% (12303 із 170767 грн) відповідно. Зіставлення ABC-, VEN- та частотного аналізів витрат на лікарські засоби групи А при гострому тонзиліті наведено у таблиці 4. Було встановлено, що

Таблиця 2. Результати АВС-аналізу лікарських призначень для лікування гострого тонзиліту

\begin{tabular}{|c|c|c|c|c|}
\hline \multirow{2}{*}{ Група } & \multicolumn{2}{|c|}{ Кількість Л3 } & \multicolumn{2}{c|}{ Витрати на Л3 } \\
\cline { 2 - 5 } & кількість призначень & $\%$ & 95806 & 56,10 \\
\hline A & 450 & 26,33 & 53006 & 31,04 \\
\hline В & 580 & 33,94 & 21955 & 12,86 \\
\hline C & 679 & 39,73 & 170767 & 100 \\
\hline Всього & 1709 & 100 & грн & $\%$ \\
\hline
\end{tabular}

Таблиця 3. Результати інтегрованого частотного/VEN/ABC-аналізу лікарських призначень для лікування гострого тонзиліту

\begin{tabular}{|c|c|c|c|c|}
\hline \multirow{2}{*}{ Група } & \multicolumn{2}{|c|}{$\begin{array}{c}\text { Частка призначень кожної категорії ліків } \\
\text { (призначень/\%) }\end{array}$} & \multicolumn{2}{|c|}{ Частка витрат на кожну категорію ліків (грн/\%) } \\
\hline & $\mathrm{V}$ & $\mathrm{N}$ & $\mathrm{V}$ & $\mathrm{N}$ \\
\hline A & $257 / 15,04 \%$ & $193 / 11,29 \%$ & 83503 грн / 48,9\% & 12303 грн / 7,2\% \\
\hline $\mathrm{B}$ & $75 / 4,39 \%$ & $505 / 29,55 \%$ & 6102 грн / 3,57\% & 46905 грн / 27,47\% \\
\hline $\mathrm{C}$ & $92 / 5,38 \%$ & $587 / 34,35 \%$ & 5448 грн / 3,19\% & 16506 грн / 9,67\% \\
\hline Всього & $424 / 24,81 \%$ & $1285 / 75,19 \%$ & 95053 грн / 55,66\% & 75714 грн / 44,34\% \\
\hline
\end{tabular}

Таблиця 4. Зіставлення ABC-, VEN- та частотного аналізів витрат на лікарські засоби групи А при гострому тонзиліті

\begin{tabular}{|c|c|c|c|c|c|c|}
\hline \multirow{2}{*}{$\begin{array}{c}\text { МНH, } \\
\text { код АТС }\end{array}$} & \multicolumn{2}{|c|}{ АВС-аналіз } & \multirow{2}{*}{$\begin{array}{c}\text { VEN-аналіз } \\
\text { (фрормальна } \\
\text { оцінка) }\end{array}$} & \multicolumn{2}{|c|}{ Частотний аналіз } & \multirow{2}{*}{$\begin{array}{l}\text { Середня вартість } \\
\text { витрат на лікування } \\
\text { одного хворого, грн }\end{array}$} \\
\hline & $\begin{array}{c}\text { сума } \\
\text { витрат, грн }\end{array}$ & $\begin{array}{c}\% \\
\text { від суми витрат }\end{array}$ & & $\begin{array}{l}\text { кількість } \\
\text { хворих }\end{array}$ & $\begin{array}{c}\% \\
\text { хворих }\end{array}$ & \\
\hline $\begin{array}{l}\text { Цесттріаксон, J01D } \\
\text { D04 }\end{array}$ & 75246 & 44,06 & $\mathrm{~V}$ & 228 & 78,62 & 330,03 \\
\hline $\begin{array}{l}\text { Різні антисептики, } \\
\text { R02A A20 }\end{array}$ & 12302 & 7,20 & $\mathrm{~N}$ & 193 & 66,55 & 63,74 \\
\hline \multirow[t]{2}{*}{$\begin{array}{l}\text { Цефуроксим, J01D } \\
\text { С02 }\end{array}$} & 8257 & 4,84 & $\mathrm{~V}$ & 29 & 10,00 & 284,72 \\
\hline & 95806 грн & $56,10 \%$ & & 450 & & \\
\hline
\end{tabular}

ISSN 2312-0967. Pharmaceutical review. 2016. № 4 
основні кошти використовувались на засоби трьох MHH: цестріаксон (J01DD04), різні антисептики місцевої дії (R02AA20) та цефуроксим (J01DC02), серед яких найбільш витратний засіб цестріаксон призначали найбільшій кількості хворих. Незважаючи на те, що цестріаксон рекомендований національним стандартом лікування гострого тонзиліту [2], він не $є$ препаратом вибору для лікування зазначеної нозології. Цефтріаксон раціональніше замінити на препарати групи пеніцилінів або цефалоспоринів першого покоління, які при однаковій клінічній ефективності проти Streptococcus pyogenes мають меншу вартість [11].

Середньовитратну групу В у більшості склали другорядні засоби категорії N 29,55 \% (505 із 1709), які в грошовому еквіваленті нараховували 27,47 \% (46905 із 170767 грн) витрат на фрармакотерапію. Життєво важливі ліки категорії $\mathrm{V}$ у групі В становили лише 4,39 \% (75 із 1709), частка витрат на які склала лише 3,57\% (6102 із 170767 грн).

До найменш витратної групи С також належали переважно другорядні засоби 34,35 \% (587 із 1709), що у вартісному вираженні становили 9,67 \% (16596 із 170767 грн) від суми витрат. Життєво важливі засоби категорії V склали 5,38 \% (92 із 1709) від усіх призначень лікарів, частка витрат на які дорівнювала 3,19\% (5448 із 170767 грн).

Таким чином, результати інтегрованого частотноro/VEN/ABC-аналізу свідчать, що за частотою лікарських призначень другорядні засоби суттєво переважали над життєво важливими, частка призначень яких склала лише 24,81 \%. Водночас фрінансові ви- трати на життєво важливі засоби були дещо більшими, ніж на другорядні, що дорівнювало 55,66 та 44,34 \% відповідно. Було встановлено, що основні грошові кошти витрачали на препарати цефртріаксону (J01DD04). Надмірні витрати на фрармакотерапію гострого тонзиліту цефралоспоринами третього покоління, на нашу думку, можна пояснити бажанням лікарів убезпечити своїх пацієнтів від клінічних невдач, пов'язаних 3 руйнуванням $\beta$-лактамазами копатогенної мікрофрлори мигдаликів більш дешевих препаратів групи пеніциліну [12]

Висновки. За результатами проведених досліджень встановлено, що основні кошти не були витрачені на необхідні та важливі лікарські засоби для лікування гострого тонзиліту, адже найбільш часто призначувані та витратні препарати можливо було замінити на дешевші засоби $з$ аналогічною клінічною ефрективністю.

Економічно більш раціональним було би починати орармакотерапію гострого тонзиліту 3 препаратів групи пеніциліну. Антибіотики широкого спектру дії цефалоспорини II- III покоління та інгібітор-захищені пеніциліни як препарати другого ешелону було би доцільно призначати лише у випадках рецидивуючого тонзиліту.

Виключення з листків лікарських призначень засобів місцевої антисептичної дії, препаратів для нормалізації мікрофрлори кишечника, глюкокортикостероїдів та дієтичних добавок, що широко призначались лікарями, також дозволило би скоротити витрати на фрармакотерапію, не впливаючи на її якість.

\section{Список літератури}

1. Машейко А. Н. Острый фарингит и тонзиллит: эпидемиология заболеваемости / А. Н. Машейко, О. В. Макаренко // Фармакоекономіка в Україні: стан та перспективи розвитку : матер. VII наук.-практ. internetконср. - Харків, 2014. - С. 64-65.

2. Протокол надання медичної допомоги хворим 3 катаральною, фолікулярною та лакунарною ангінами (J03 за MKX-10) : наказ МОЗ України від 24 березня 2009 р. № 181 Про затвердження протоколів надання медичної допомоги за спеціальністю «отолярингологія» // Міністерство охорони здоров'я України : офріційний веб-портал. - Режим доступу: http://www.moz.gov.ua/ua/ portal/dn_20090324_181.html

3. Національні рахунки охорони здоров'я (НРО3) України у 2013 році: [стат. бюлетень]. - Київ : Держкомстат України, 2015. - 213 с. // Державна Служба Статистики України : офріційний веб-портал. - Режим доступу: https:// ukrstat.org/uk/druk/publicat/Arhiv_u/15/Arch_nroz_bl.htm_

4. Лехан В. М. Стратегія розвитку системи охорони здоров'я: український вимір / В. М. Лехан, Г. О. Слабкий, М. В. Шевченко // Україна. Здоров'я нації. - 2010. - № 1. - С. $5-23$.

5. Ривак Т. Б. Оцінка думки населення щодо якості медикаментозного лікування / Т. Б. Ривак,

А.Б. Зіменковський//Клінічна фармація, фрармакотерапія та медична стандартизація. - 2012. - № 3. - С. 9 - 15.

6. Державний фрормуляр лікарських засобів (випуск восьмий) : наказ від 14 березня 2016 р. № 183 Про затвердження восьмого випуску Державного формуляра лікарських засобів та забезпечення його доступності // Міністерство охорони здоров'я України : офріційний веб-портал. - Режим доступу: http://www.moz.gov.ua/ua/ portal/dn_20160314_0183.html_

7. Оцінка клінічної та економічної доцільності використання лікарських засобів у лікувально-профрілактичному закладі (супровід фрормулярної системи) : методичні рекомендації / А. М. Морозов, Л. В. Яковлєва, Н. В. Бездітко [та ін.]. - Київ, 2013. - 36 с.

8. Different antibiotic treatments for group A streptococcal pharyngitis / M. L. van Driel, A. I. De Sutter, N. Keber [et al.] // Cochrane Database of Systematic Reviews. - 2013. - № 4. - P. 1-70.

9. Пошукова система «Реєстр оптово-відпускних цін на лікарські засоби МОЗ України». - Режим доступу: http://www.moz.gov.ua/ua/portal/register_prices_drugs/.

10. Пошукова система «Середньозважена роздрібна вартість лікарських засобів в Україні». - Режим доступу: http://compendium.com.ua/prices.

ISSN 2312-0967. Фармацевтичний часопис. 2016. № 4 
11. Clinical Practice Guideline for the Diagnosis and Management of Group A Streptococcal Pharyngitis: 2012 Update by the Infectious Diseases Society of America / S. T. Shulman, A. L. Bisno, H. W. Clegg [et al.] // Clinical Infectious Diseases. - 2012. - Vol. 55, № 10.
- Р. 86-102.

12. Дронов И. А. Проблемы выбора антибактериальной терапии при стрептококковом тонзиллофрарингите у детей / И. А. Дронов, Н. А. Геппе, У. С. Малявина // Лечащий врач. - 2014. - № 1. - С. 7 - 10.

\title{
КЛИНИКО-ЭКОНОМИЧЕСКИЙ АНАЛИЗ РАСХОДОВ НА ФАРМАКОТЕРАПИЮ ОСТРОГО ТОНЗИЛЛИТА В УСЛОВИЯХ СТАЦИОНАРА
}

\author{
А. Н. Машейко, О. В. Макаренко, В. В. Маврутенков \\ ГУ «Днепропетровская медицинская академия Мз Украины», Днипро
}

Резюме: в статье приведены результаты интегрированного частотного/VEN/ABC-анализа целесообразности фринансовых затрат на проведение фрармакотерапии острого тонзиллита. Установлено существенное преобладание частоты врачебных назначений второстепенных препаратов (N) над жизненно важными (V) в количественном выражении и незначительное преобладание жизненно важных препаратов над второстепенными в стоимостном выражении. Из полученных результатов можно сделать вывод, что основные денежные средства не расходовались на необходимые и важные лекарства для лечения острого тонзиллита.

Ключевые слова: острый тонзиллит, частотный анализ, ABC-анализ, VEN-анализ, лечение в условиях стационара.

\section{CLINICAL ECONOMIC ANALYSIS OF THE FINANCIAL COSTS FOR THE PHARMACOTHERAPY OF ACUTE TONSILLITIS IN THE CONDITIONS OF THE HOSPITAL}

\section{A. M. Masheiko, O. V. Makarenko, V. V. Mavrutenkov}

Dnipropetrovsk Medical Academy

Summary: the integrated frequency/VEN/ABC-analysis of the financial costs for pharmacotherapy of pediatric patients with acute tonsillitis was conducted. It was found that the frequency of prescribing non-essential medicines greatly prevailed over vital medicines. At the same time, the financial expenses for vital medicines were a little higher than for non-essential medicines. Therefore, it can be concluded that the main part of money was not spent on the necessary and important medicines for the treatment of acute tonsillitis.

Key words: acute tonsillopharyngitis, frequency analysis, ABC-analysis, VEN-analysis, hospital-based treatment. 